\title{
Resisting Abusive Legalism: Electoral Fairness and the Partisan Commitment to Political Pluralism
}

\author{
Representation: Journal of Representative Democracy \\ Published Online: April 8, 2020 \\ DOI: $10.1080 / 00344893.2020 .1744701$
}

Lise Esther Herman, Lecturer in Politics at the University of Exeter (corresponding author):

L.herman@exeter.ac.uk

\author{
Russell Muirhead, Robert Clements Professor at Dartmouth College \\ russell.muirhead@dartmouth.edu
}

\begin{abstract}
This paper focuses on how electoral fairness is vulnerable to abuse by self-interested partisans-especially abuse that conforms to legally and constitutionally sanctioned procedures. This phenomenon sometimes labelled 'abusive legalism,' challenges the aspiration to design institutions that depend only on rationally self-interested actors for their endurance. Electoral fairness in particular, we argue, depends on partisans who endorse and act from a commitment to political pluralism. We identify the normative reasons that make sense of such a commitment, and consider the difficulties involved in applying this commitment to practical projects of institutional reform. In this process, we define a theoretical framework that both adds to the expanding literature on democratic partisanship and provides a basis for further empirical research on the mechanisms of democratic backsliding.
\end{abstract}

Key words: Partisanship; Electoral fairness; Political Pluralism; Normative Political Theory; Democratic backsliding

Acknowledgements: We would like to thank the faculty at the following meetings for sharing their reactions to earlier drafts of the paper: the "Political Theory Reading Group" organized by the Centre for Political Thought at the University of Exeter in November 2018, the "Conference on Political Parties and the Constitution," co-hosted by the Bonavero Institute of Human Rights and the Programme for the Foundations of Law and Constitutional Government at Oxford University in June 2019; the workshop on "Truth, Power, and the Foundations of Democracy" at Dartmouth College in August 2019 and the workshop on "The nature and transformation of contemporary political regimes" organized by the Centre for Political Thought at the University of Exeter in February 2020. In particular, we would like to thank Jonathan Turner at the Oxford Faculty of Law and Chris Lewis of the Harvard Society of Fellows for their written commentary, probing criticisms, and helpful suggestions. We are particularly grateful to the four anonymous reviewers for this journal, whose incisive suggestions and criticisms were essential to strengthening the argument. Finally, we thank Sam Issacharoff of NYU Law School for sharing his thoughts on the vexing ways populist leaders can abuse reforms that seem democracy-enhancing. 
In the past decade, the optimism that surrounded the "third wave" (Huntington, 1991) of democratization after the fall of the Berlin wall has receded. It has given way to a new pessimistic consensus centred on the erosion of constitutional essentials and democratic rights in new and old democracies alike (Freedom House, 2019b; Lührmann, Grahn, Morgan, Pillai, \& Lindberg, 2019; Lührmann \& Lindberg, 2019; Öniş \& Kutlay, 2019). Political actors that claim to speak in the name of the people are orchestrating novel forms of democratic backsliding, defined as the "state-led debilitation or elimination of any of the political institutions that sustain an existing democracy" (Bermeo, 2016, p. 5). While the use of violent and illegal measures to undermine democratic institutions is waning, more incremental and subtle instruments of democratic erosion are increasingly widespread.

These legal instruments, which we group under the umbrella term abusive legalism, allow legitimately elected governments using procedures provided by the democratic framework itself and consistent with a nominal respect for the rule of law to undermine the integrity of democratic institutions. Political majorities in countries such as Hungary, Poland, Turkey, the United States and the United Kingdom, are changing the rules of the political game to favour themselves without using force or fraud (Bogaards, 2018; Cinar, 2019; Norris, 2017a; Pech \& Scheppele, 2017; Sözen, 2019; Stewart, 2017). At the extreme, these processes can result in "illiberal or diminished forms of democracy" (Meyerrose, 2020) where electoral fairness is fundamentally undermined: elections are still free, to the extent that a variety of parties can compete, but have fundamentally ceased to be fair.

In this paper, we argue that these contemporary processes of democratic backsliding are best explained not by the insufficient robustness of existing institutions, but by the weakness of normative commitments to democratic processes among partisan political actors. Drawing on normative democratic theory and especially theories of democratic partisanship, we posit that 
electoral fairness - defined as a principle according to which all political parties that uphold democratic constitutional essentials compete on equal terms for votes and, through this, for political power-depends on mainstream partisans who have a commitment to political pluralism. By mainstream partisans we refer to those political actors who stand with parties that are viable contenders for office, rather than of those at the fringe of the political spectrum. We are particularly concerned with partisans who seek office and hold office, and not principally with those who passively belong to or identify with a party. The commitment to pluralism of these actors entails a negative affirmation, a refusal to claim that they are the sole representatives of the people - and a positive one, an acceptance of the legitimacy of parties and groups that make rival claims to govern. We show that democracy understood in the most minimal sense requires partisans who are sufficiently pluralist to resist the temptation of abusive legalism and, who are instead inclined to create and to support procedures that produce electoral fairness.

By bridging the empirical study of democratic backsliding and contemporary theories of democratic partisanship, this paper contributes to both literatures. It develops existing standards of pluralist partisanship and specifies the normative reasons that could reasonably motivate partisans to endorse political pluralism, and it locates the connection between the commitments of partisans and their institutional practices. The paper shows that pluralist partisanship is not solely a normative ideal relevant to political theorists, but an empirical condition for the endurance of basic procedures ensuring electoral fairness, and thus democracy in a minimal sense. In this process, it establishes a theoretical framework on which further empirical research can build and opens avenues for future enquiry into the role of pluralist partisanship in resistance to abusive legalism today.

The paper proceeds in two main parts. In the first part we consult the well-established idea that electoral fairness depends on well-designed procedures and sustained competition 
between self-interested rational actors for its endurance - not individual virtue. We argue that abusive legalism, which is the new face of democratic backsliding today, puts into question this rational institutionalist model. The second part of the paper responds to this dilemma by arguing that pluralist norms - and particularly when they are held by mainstream partisans - are necessary for the survival of minimal procedures that ensure electoral fairness. We identify the normative reasons that make sense of the partisan commitment to political pluralism and consider the implications of this commitment for mainstream partisans involved in projects of institutional reform.

\section{The heroic view of institutions and the challenge of abusive legalism}

We begin by consulting an ideal-type understanding of the relationship between welldesigned political institutions and the selfish motivations of political actors - what we call the heroic view of institutions. First, we show that this view has a long tradition starting with

enlightenment political thought, and then argue that it has remained influential in rational institutionalist models of democracy up to the present. Second, we show that modern forms of democratic backsliding, whereby elected majorities erode democratic institutions while remaining within the realm of legality, pose a fundamental challenge to the heroic view. This opens the door to re-considering the importance of normative commitments in the endurance of those minimal procedures that guarantee electoral fairness.

\section{Electoral fairness, institutional design and elite self-interest}

In this paper, electoral fairness is understood a principle according to which all political parties that uphold democratic constitutional essentials should compete on equal terms for votes and, through this, for political power. In democratic systems, this principle is given institutional expression through a body of procedures that regulate elections, including electoral systems 
determining the methods by which votes are translated into seats, the delimitation of constituencies, campaign law on party funding, or the rules surrounding electoral suffrage. But electoral fairness is also guaranteed by a broader set of rules that affects the capacity of parties to fulfil their linkage function ahead of electoral periods, for instance rules ensuring their equal access to the media or to judicial redress. Many theorists define electoral fairness more expansively, to include the extent to which given procedures amount to a fair representation of different groups of citizens (see for instance Disch, 2011; Dovi, 2007; Mansbridge, 2003; Saward, 2010; M. S. Williams, 2000). Within this dynamic literature on what representation entails in the ideal, Williams for example argues that standards of fair representation should consider the identity of representatives, not solely the procedure by which parties compete for power (M. S. Williams, 2000). The focus of our paper is narrower, as it is concerned with the conditions of endurance of the more minimal array of rules that ensure free and fair elections, rather than the conditions that would be necessary to fully realize the most demanding ideals of representation. To this extent we focus on the survival of the procedural dimension of democracy, understood as the "institutional arrangement for arriving at political decisions in which individuals acquire the power to decide by means of a competitive struggle for the people's vote" (Schumpeter, 1950, p. 269).

Democratic theory has long been divided between a minimalist school, which has provided the theoretical underpinning for much of contemporary political science, and a more normative strand (Elliott, 1994; Skinner, 1973; van Biezen \& Saward, 2008). One of the key differences between these schools of thought is the respective weight they place on institutionalised procedures and more intangible norms in defining democracy, as well as on the conditions of its endurance. According to the minimalist strand, well-designed procedures and institutions are the prime condition for the perpetuation of a democratic system by which elites compete in free and fair elections for access to political power. This view of institutions 
is deeply grounded in Western political thought, and can be labelled as "heroic" to the extent that it is intimately linked with the assumption that "liberal democracy (...) can function in the absence of civic virtue" (Rosenblum, 1998, p. 10).

For many Enlightenment thinkers, institutions could supply what virtue could not: with the right constitution, an amoral input would produce a moral output. Or as Kant so emphatically put it, "the problem of organizing a state, however hard it may seem, can be solved even for a race of devils, if only they are intelligent" (Kant, 1795). In this understanding, constitutional design acts as an institutional solution to the problem of virtue - namely, that a commitment to justice and the public good is unreliable. As stressed by Madison, who defended the design of the American constitution by reference to its capacity to counteract the deficiencies of human nature, "(if) men were angels, no government would be necessary" (cited in D. L. Williams, 2014, p. 162). Because "enlightened statesmen will not always be at the helm," Madison said, founders (or political scientists) must design constitutional institutions that would make up for the deficit of those virtues enlightened statesmen would presumably supply (Madison, 1787). In line with this idea, he advocated for districts so large that their diversity would overwhelm natural communities with a common way of life and a shared interest (Madison, 1787). His other institutional designs included bicameralism, where "ambition must be made to counteract ambition," and artful division of powers where each department - the legislative, executive, and judicial-shares in a measure of the other department's functions (Madison, 1788). To this extent, electoral fairness is produced not by well-meaning political elites, but by a body of procedures that constrain and direct asocial motivations transforming them to achieve social or mutually beneficial results. As Mandeville and Smith thought private vices could unwittingly produce public benefits, so Madison hoped for something similar if institutions channelled individual ambition and selfishness the right 
way (Mandeville, 1732; Smith, 1776). Democratic institutions, like the invisible hand of the market, would turn the sum of selfish interests into a collective good.

This tradition echoes the economic theories of democracies that flourished in the 1950s, and which still structure the underlying assumptions of much contemporary political science (Dahl, 1956, 1971; Downs, 1957). These theories are generally labelled as rationalinstitutionalist, because they posit the self-interested nature of political elites and view the endurance of democracy as guaranteed by well-designed institutions and a highly competitive political arena (see for example Clark, 2002; O'Donnell, Schmitter, \& Whitehead, 1986; Przeworski, 1991, 1999; Schmitter \& Karl, 1991; Schneider \& Schmitter, 2004). Electoral fairness - whereby prospective leaders are treated equally in the process of competition for votes, and thus hold comparable chances to convince citizens and access political power-is guaranteed not because individuals are committed to the regime as such, but because a welldesigned system creates incentives towards its perpetuation. In such a setting, rational individuals have a greater interest in accepting limitations to their own power, and thus to play by fair rules, than in attempting to subvert the system. Essentially, self-interest is the key reason why alternation between competitors gets started where it has never happened before (Przeworski, 2015, pp. 17-18). Given partisans are mainly motivated by political power, their first preference may be to undermine the freedom and fairness of elections, for instance by exiling, imprisoning, of killing their opponents. If they are rational, however, they will also be sufficiently prudent to only attempt these actions if the associated risks are minimal, and the benefits sufficiently certain. Well-designed institutions and a highly competitive arena raise the potential costs of choosing violent alternatives: the division of powers may put them out of reach, while a numerous political opponent would make the obliteration strategy unlikely to succeed. 
This type of rational institutionalism was the central theoretical underpinning of democracy and democratization studies up to the late 2010 s, with a strong focus on institutional indicators to assess the progress of newly established democracies. It explains why institutional design has been such a central topic in the literature, driving debates concerning which electoral system best ensures democratic viability and prevents regime backsliding in the context of newly established democracies (see for example L. Diamond \& Plattner, 2006; Lardeyret, 2006; Lijphart, 1991; Meisburger, 2012; Reynolds \& Carey, 2012; Shapiro, 2018). Much of the comparative scholarship on democratic consolidation up to the late 2000s also relied on institutional criteria to assess the progress of individual countries on what was often conceived as a unidirectional process. In the case of Central Eastern Europe (CEE) for instance, this included among other measures the compliance with the EU's accession conditions, the institutionalization of party competition measured through its strength, stability and the regularity of alternation, as well as the formalization of civil and political rights into law (Casal Bértoa \& Mair, 2010; Levitz \& Pop-Eleches, 2010; Schneider \& Schmitter, 2004). On the basis of such indicators, democratization appeared until very recently to be progressing in most corners of the globe. Not only did the number of countries organizing minimally free and fair elections steadily increase over time in what Huntington labelled "waves of democratization" (Freedom House, 2006; Huntington, 1991), but newly democratized regions such as Central Eastern Europe appeared to be consolidating at record speed (Clark, 2002; King, 2000; Schneider \& Schmitter, 2004). To this extent, the rational institutionalist paradigm largely contributed to the more general climate of optimism concerning the future of liberal democracy that followed the end of the Cold War. 


\section{Abusive legalism as a challenge to the heroic view}

In the past decade, this hopeful tone has been made largely obsolete by a global context of erosion of constitutional essentials and democratic rights affecting new and old democracies alike (Freedom House, 2019b; Lührmann et al., 2019; Lührmann \& Lindberg, 2019; Öniş \& Kutlay, 2019). In countries such as Hungary, Poland, Turkey, the United States or the United Kingdom, political majorities on the right of the political spectrum have been changing the rules of the political game to favour themselves, thus undermining the fairness of the electoral process, through constitutional amendments, by-passing intermediary institutions and the misuse of political appointment (Bogaards, 2018; Cinar, 2019; Norris, 2017a; Pech \& Scheppele, 2017; Sözen, 2019; Stewart, 2017). These processes have led to a radical change in the focus of democracy studies, from what appeared yesterday to be an inexorable extension of the liberal world, to its heightened vulnerability in the populist era. In what follows, we argue that the emerging literature on contemporary democratic backsliding, defined as the "state-led debilitation or elimination of any of the political institutions that sustain an existing democracy" (Bermeo, 2016, p. 5), raises fundamental challenges for the rational institutionalist framework. ${ }^{1}$

Today, contemporary democratic backsliding has little to do with poorly designed institutions failing to generate compliance from political actors. Indeed, contemporary abuse is less likely than in the past to take place through the blatant violation of law, the arbitrary use of force, violent coup or outright institutional breakdown that ill-designed institutions would have failed to stop. Rather these processes are incremental and orchestrated by elected political elites within pre-existing legal channels (Bermeo, 2016). We use the term abusive legalism to

\footnotetext{
${ }^{1}$ Criticism of the procedural understanding is not new and has bloomed on various disciplin- ary grounds since the 1970s, including political theory, political sociology and political history. As argued in later sections, scholars have namely pointed out how the rational insti- tutionalist paradigm negates the essentially normative character of democracy itself and neglects the role of citizens and their values in dynamics of democratisation (Pateman, 1971; 1970 [1970]; Skinner, 1973; Weyland, 2002). While many scholars have acknowledged these difficulties and improved institutionalist models accordingly (for an overview, see Hall \& Taylor, 1996; Kato, 1996), the fundamental premise that institutional design forms the bedrock of democracy has nevertheless continued to dominate the study of politics.
} 
designate those instruments of democratic backsliding that involve using procedures provided by the democratic framework itself, with a nominal respect for the rule of law, to undermine democratic institutions. ${ }^{2}$ According to Bermeo, the two most common techniques of abusive legalism consists in executive aggrandisement, the extension of the formal power of ruling executives over previously independent institutions such as the judiciary or the media, and the strategic manipulation of elections, with changes to the rules of the game that favour incumbents. When pushed to an extreme, these processes lead to the replacement of democratic regimes by competitive authoritarian or hybrid ones (Levitsky \& Way, 2020). Elections remain free to the extent that a plurality of opponents can compete, but electoral fairness is fundamentally hampered: the electoral playing field is tilted to the extent that only one party, the one in power, has a real chance to win.

This incremental erosion of democratic essentials appears largely disconnected from the design of democratic institutions and their resulting strength. If one considers studies using institutionalist criteria to assess democratic consolidation in CEE up to the late 2000s for instance, Hungary was systematically considered as a frontrunner. Until 2010, the country displayed the most institutionalized party system in CEE, with strong elite competition and regular alternation between two main parties, and a robust institutional framework compared with other countries in the region (Casal Bértoa \& Mair, 2010; Grzymala-Busse, 2007; Lewis, 2006; Sikk, 2005). It was also among the first states to reach the EU's Copenhagen criteria, thus completing the necessary democratic standards to start accession negotiations in 1998 (Batory, 2008). Since 2010 however, the country has become one of the clearest examples of modern-day democratic backsliding, with Fidesz's two-third majority initiating a radical recasting of the constitutional framework to its own benefit (for an overview, see Bogaards,

\footnotetext{
${ }^{2}$ Various other terms have been used by constitutional lawyers to designate the same phenomenon, for example "stealth authoritarianism" (Varol, 2015), "autocratic legalism" (Scheppele, 2018) or "abusive constitutionalism" (Landau, 2013).
} 
2018; Herman, 2016; Scheppele, 2013b). Independent rating agencies that rely on procedural criteria having systematically downgraded Hungary's former status as a consolidated democracy over the past decade (see for instance Freedom House, 2019a). The institutional reforms affecting electoral laws but also the media sector, the judiciary, and parliamentary procedures have neither involved breaking the law nor using violence against political opponents; rather, the governing majority exploited the procedures offered by the pre-existing democratic system to undermine it.

This reasoning also applies to the analysis of backsliding in more established democracies. The United States, the institutions of which have been designed precisely to avoid abuse of power, has been faced with similar challenges. In North Carolina for instance the Republican-controlled state legislature has passed a series of measures to diminish the powers of the incoming Democratic governor, Roy Cooper, along with targeted gerrymandering and selective voter suppression. These reforms have motivated the independent, Electoral Integrity Project to rank North Carolina as a flawed democracy, scoring close to Cuba, Indonesia and Sierra Leone in its 2016 integrity score of 58/100 (Norris, 2017b; Reynolds, 2016). Since then, Republican legislatures have made similar moves to diminish the power of Democratic governors in both Wisconsin and Michigan in the wake of the 2018 gubernatorial elections.

The malleability of democratic institutions and their openness to rule abiding forms of abuse challenges some of the basic tenets of the rational institutionalist framework: that institutions are exogenous to the political process itself, and that they endure over time if they provide actors with the right incentives towards compliance. In practice, the forms taken by democratic backsliding today reflects the new choices that political actors face, less between compliance and violation of the law, and more between whether or not they should change the law to suit their interests. One could have an institutionalist response to this dilemma and advise 
limiting the ability of elites to change the rule of the game. ${ }^{3}$ However, any institutional solution creates loopholes that can be exploited at little cost by elites. Even when constitutional amendments are practically infeasible, such as in the case of the US, constitutional review, ordinary legislation and executive decisions will influence the rules of the political game and can be manipulated to this effect. Furthermore, and as further discussed in the last section of this paper, some flexibility is necessary to allow institutional frameworks to adapt to new circumstances and, in many historical cases, to become more democratic over time. The reinterpretation of the $14^{\text {th }}$ amendment by the US Supreme Court during the Civil Rights Movement for instance granted minorities greater access to their civil and political rights, but also required that an institution vulnerable to political appointments be able to make decisions of constitutional significance in a system that makes amendments otherwise very difficult (Ackerman, 2018).

Abusive legalism also fundamentally challenges another key tenet of rational institutionalist frameworks: that institutions can function in the absence of civic virtue as long as political elites are rational. As highlighted above, the malleability of democratic institutions is necessary for democracies to emerge and progress, but this very malleability also opens the door to their manipulation and demise. For actors concerned only with maximizing their own political power, the rational choice is to resort to this type of manipulation. Blatant noncompliance with democratic rules — such as orchestrating a military coup or massive voter fraud - do come with important risks, and these risks have grown in a global context where elections have become the norm. Today, elections are under intense domestic and international scrutiny, with the systematic presence of external observers and the instantaneous diffusion of compromising information through social media; the integrity of elections also increasingly

\footnotetext{
3 These could include eternal clause of the type found in the German constitution, delaying the time of implementation of any constitutional reform by the time of a mandate, or raising the parliamentary threshold for constitutional amendments.
} 
conditions aid and trade cooperation (Bermeo, 2016; Meyerrose, 2020). But the potential costs associated with incremental changes to the rule of the game are far lower, precisely because they take on the veneer of legality. For this reason, specific legal measures cannot necessarily be identified as abusive when they are considered individually, rather than as one element of a wider system of abuse. As Scheppele insists, this is why "governance checklists" do not work to diagnose contemporary forms of abusive legalism operating in Hungary (Scheppele, 2013a). Taken individually many of Fidesz's measures find justifiable equivalents in other democratic contexts. Taken together however, they result in a system of competitive authoritarianism where elections are still free but heavily skewed towards the party in power. ${ }^{4}$ This system has given the EU very little grip to impose sanctions: although a decade of abusive legalism means Hungary does not comply with the basic democratic standards needed to become a Member States, the country continues to apply EU law and, when found in infringement, also upholds CJEU decisions. ${ }^{5}$

This form of democratic backsliding is therefore relatively straightforward to explain from a rational choice perspective: once it is accepted that institutions are malleable rather than exogenous to the political process, and that manipulating the rules comes at little cost, it is to be expected that power-maximizing political actors will engage in such behaviour. Conversely, however, democratic endurance is far more difficult to explain within these parameters: abusive legalism represents a fundamental challenge to the idea that rational actors can ever maintain democratic institutions. Why would power-maximizing, rational actors ever choose not to exploit institutional loopholes and undermine the procedures that guarantee electoral fairness if

\footnotetext{
${ }^{4}$ For instance, Fidesz has justified its recent December 2018 decision to create a new administrative branch of the judiciary on the basis that it follows Venice Commission recommendations and that countries such as Austria, the Czech Republic, Germany and Poland already had such a system in place. In practice however, this measure allows the Hungarian Minister of Justice to nominate a large number of new judges in charge of sensitive issues such as cases of corruption, the right to protest or electoral regulations

5 There are other reasons that help explain the EU's relative inaction, namely a lack of appropriate legal mechanisms to evaluate and sanction this type of abusive legalism (see Sedelmeier, 2014, 2017)
} 
this would result in certain benefits and entails few risks? How can we explain the decades of democratic stability in post-war Western Europe for instance, permeated with examples of the use of amendment or re-drafting provisions (Alexander, 2001, pp. 263-264; Renwick, 2010)? This is particularly puzzling in 'high-stakes' frameworks such as France or the UK, that allow for the emergence of strong majorities with weak limitations on their power, and increase the costs associated with electoral defeat. While elite self-interest easily explains democratic backsliding, it largely fails to explain cases when democracy persists. For this purpose, it is essential to consider the role of certain norms among elites in sustaining democratic regimes.

\section{Pluralist partisanship as a condition for electoral fairness}

The remainder of this paper draws on normative democratic theory to provide a response to this dilemma, arguing that a pluralist commitment from mainstream partisans is necessary to avoid abusive legalism and thus ensure the persistence of procedures that guarantee electoral fairness. Its starting point is the well-accepted position among normative democratic theorists and students of political culture that beyond well-designed institutions, democracy depends on certain norms that are widely diffused and generally supported. This paper contributes to this perspective by showing that the normative commitments of mainstream partisans support the endurance of democracy understood in its most minimal sense. More specifically, their commitment to political pluralism acts as a break to abusive legalism and is thus a condition for continued electoral fairness. We show that pluralist partisanship is not an unrealistic ideal and that there are normative reasons that make sense of and can reasonably motivate the commitment to political pluralism. We conclude by discussing the ethics of institutional reforms and what kind of institutional changes pluralist partisans would and would not support.

\section{Normative understandings of democracy and the role of partisans}


The idea according to which democracy depends on certain attitudinal and behavioural norms being entrenched within society has a long-established tradition, although it has certainly been more influential among political ethnographers, sociologists and normative political theorists than in the mainstream of political science. Much of normative democratic theory is built on the assumption that liberal democracy is more than a procedural arrangement and constitutes instead a distinct political ethos or way of life (Cruickshank, 2014; Galston, 2002, 2005; Hallowell, 1954; Kateb, 1981; Lefort, 1988; Macedo, 1990; Mouffe, 2000; Rosenblum, 1989; Ryn, 1978). To this extent, democracy rests on its members sharing "implicit norms determining notions of just and unjust, good and evil, desirable and undesirable, noble and ignoble" (Lefort, 1988, pp. 2-3). For those democratic theorists who have taken an interest in institutional design, this endeavour is not meant to sustain institutions in the absence of a value commitment to democracy, but to reflect and instantiate the fundamental political values of freedom and equality (see Beitz, 1989; Christiano, 1996; Ganghof, 2016; Anthony J. McGann, 2006; Anthony J. McGann, 2013; van der Hout \& McGann, 2009). ${ }^{6}$

Students of political culture share some of these assumptions. Cultural and discursive institutionalists especially assume that the functioning of institutions depends not only on the rationality of self-interested individuals, but on the internalisation by these actors of specific norms of behaviour and discourse (see for instance Coppedge, 2012, p. ch. 8; Hall \& Taylor, 1996; Schmidt, 2008). In this understanding, electoral procedures only work to produce fairness when they are "inscribed in shared forms of life" (Mouffe, 2000, p. 68), and thus resonate with norms that are otherwise being defended, promoted and diffused by an array of actors in society,

\footnotetext{
${ }^{6}$ With some exceptions (Beitz, 1989), these democratic theorists favour proportional representation because it instantiates political equality more effectively than single-member districts. Within this school of thoughts, disagreements on the contours of fair institutional design mostly concern how voting procedures should implement majority rule in Parliament, and whether pre-electoral or post-electoral coalition making are normatively desirable (for an overview, see Ganghof, 2016).
} 
including the media, schools and, as discussed below, political parties themselves. To this extent, democratization entails certain attitudinal transformations to ensure the survival of democratic regimes on the long run, namely the development and maintenance of elite and mass support for the regime (L. J. Diamond, 1994; Easton, 2009).

We contribute to this school of thought by arguing that, at the micro level, mainstream partisans and the extent to which they uphold pluralist political commitments have a central role in these processes. These commitments are at the heart of the mechanisms of democratic endurance or backsliding precisely because they determine whether partisans resist or indulge in abusive legalism when the opportunity arises. As compared to lay citizens, greater political responsibilities fall on partisans - those citizens who stand with others and act in concert in pursuit of translating a certain vision of the common good into governmental policy through competing in elections (Bonotti, 2011, pp. 20-22; Herman, 2017; Muirhead \& Rosenblum, 2006, p. 104; White \& Ypi, 2010, 2011; 2016, pp. 8-32; 55-101). The position of partisans in the public sphere - with privileged access to financial resources, media attention, law-making and key administrative positions - lends them significantly larger amounts of political power than other citizens. As we have noted, mainstream partisans are those whose parties hold the potential of wining national-level elections, forming political majorities and heading governmental coalitions, whether in government or in opposition at any given moment in time.

Because of the malleability of democratic institutions, discussed above, mainstream partisans are not only the bearers of pre-existing structures but are also shapers of their political environment. Institutions are largely endogenous to the political process itself and result from complex decision-making processes that involve mainstream parties. These not only have a key role in the making of these procedures at the birth of constitutions, but also in the subsequent democratization of constitutional settlements - this is what Schattschneider had in mind when he said that "parties have been the makers of democratic government" (Schattschneider, 2009 
[1942], p. 1). For democracy to endure, partisans need to do more than simply fulfil the legal obligation of complying with the rules of the game; they also need to fulfil the moral obligation not to exploit the system's unavoidable loopholes and change the rules of the game to their own advantage. As discussed earlier, mainstream partisans have the power to hollow out democratic institutions at little cost, and without something that constrains self-interest—some kind of an ethical commitment - they most likely will.

\section{A theory of pluralist partisanship}

A commitment to political pluralism of mainstream partisans is one of the single-most important ethical brakes on partisans using their power to indulge in abusive legalism and shape institutions in their own interest. This pluralist commitment has a negative and a positive dimension. In the first instance, it requires that partisans reject holism, or the view that the people are essentially one and that there is therefore only one legitimate way of understanding the common good (Rosenblum, 2008, pp. 124, 363). Contemporary political science has already highlighted the close relationship between abusive legalism and an increasingly anti-pluralist political climate. For example, the legal practices of populist political actors, who defend a holist claim to political representation pitting the virtuous, singular people against the corrupt elite (Mudde, 2007; Werner-Müller, 2016), illustrate the risks that holist partisans pose for institutions that secure electoral fairness. Indeed, anti-pluralist populism has become the dominant discourse of justification of abusive legalism today, so much so that certain scholars use the term "populist constitutionalism" to label these practices (Blokker, 2019; Blokker, Bugaric, \& Halmai, 2019; Müller, 2017). Populist political actors claim that they have a democratic mandate for institutional reform anchored in their unique capacity to address the people's grievances; conversely, political opponents or intermediary institutions that oppose populist actors are depicted as illegitimate and a threat to the common good (Albertazzi \& Mueller, 2013; Müller, 2017). 
The perils of affective polarization, a form of partisan division anchored in the emotional rejection and hatred of opponents, also illustrates the link between anti-pluralism and democratic erosion (Iyengar, Lelkes, Levendusky, Malhotra, \& Westwood, 2019). Polarized party systems lead to citizen dissatisfaction, governmental gridlock, constitutional abuse and, in extreme cases, democratic breakdown (Ezrow \& Xezonakis, 2011; Lijphart, 2012; Linz, 1978; Thurber \& Yoshinaka, 2015). Lack of respect for opponents create few incentives for cooperation or reasons to refrain from manipulating procedures in ways that sacrifice electoral fairness.

Beyond the rejection of holism, partisans committed to pluralism have a more positive ability to recognize that, even if they hold strong political convictions, democratic politics is characterised by the co-existence of a plurality of legitimate claims to the common good. Consequently, pluralist partisans accept their party's status as only a part in the polity, though they may strive to represent the whole, and thus the necessity to uphold procedures that guarantee electoral fairness (Bonotti, 2011; Sartori, 1976, ch. 1). They understand that the authority conferred by elections is necessarily and always of a provisional nature. The affirmation of political pluralism thus asserts what Lefort coined "the revolutionary and unprecedented feature of democracy", that "the locus of power becomes an empty place (...), it cannot be occupied - it is such that no individual and no group can be consubstantiated with it" (Lefort, 1988, p. 16).

Pluralist partisanship is a feature of political culture, defined as "the pattern of distribution of orientations members of a political community have towards politics" (Dawson and Prewitt, 1969, cited in Pateman, 1971, p. 293). Like other dimensions of political culture, the emergence or erosion of pluralist partisanship is likely to depend not only on the agency and morality of political actors, but on a wide array of contingent historical, political, economic and social factors. It is beyond the scope of this paper to disentangle these. It is nevertheless 
important to state that we do not consider cultural traits such as the disposition of partisans to pluralist commitments as irrevocable, either present or absent in any particular society, but rather as open to change (Pateman, 1971; White, 2009). As shown by Sartori, the consolidation of first-wave democracies in the $19^{\text {th }}$ century was accompanied by a progress of pluralist norms within party systems (Sartori, 1976); these same polities are today seeing a strong erosion of norms of tolerance which, as discussed previously, is also driving processes of democratic backsliding.

Before expanding on the role of pluralist partisanship in supporting electoral fairness, we would like to canvass some of the normative reasons that might cause partisans to view a commitment to political pluralism as right in and of itself. Such a commitment is not a given since, after all, the commitment to a party itself, which is the heart of partisanship, is connected to a sense that the ideas and policies of one's own party are superior to those of their opposing parties. This is why partisanship has long been associated with factionalism and intransigence rather than toleration of opponents and capacity for compromise (for an overview, see Ball, 1989; Rosenblum, 2008). From this angle, partisanship appears hardly compatible with moral pluralism, or the belief that there is no ultimate truth in political matters and that there are instead a variety of goods that cannot rank-ordered or subsumed according to one ultimate good (Galston, 2002, p. 30). For many partisans, a belief in moral pluralism might even impede their fulfilling of other democratic duties, such as the representation and mobilization of certain categories of voters. To engage citizens and offer them meaningful alternatives to choose from, partisans cannot see all political claims as possessing equal merit; they need to argue the superiority of their own program and criticise their opponents' platform (Mouffe, 2005; White \& Ypi, 2011).

What then, are the normative reasons that might support the partisan commitment to political pluralism? We highlight two that make sense of this commitment: epistemic humility 
and epistemic respect. First, partisans with a sense of epistemic humility believe that, while truth in politics exists, no single individual, including themselves, can ever fully apprehend it. In John Stuart Mill's vocabulary partisans see each other as "one eyed," only capable of discerning a partial truth which, when confronted with the perspective of others, will lead to a more complete understanding of political reality (Muirhead, 2014, p. 99). To this extent, pluralist partisans know that the practical questions of politics are many-sided, and that perfect certainty is rarely warranted. For this reason, they display humility in their own capacity to full discern a given political truth.

Notwithstanding the self-righteous tenor of partisan politics, epistemic humility would seem warranted with respect to most issues. To be sure, for some practical political questions, there may be examples where one side of a question seems almost entirely right and the other almost entirely wrong. For instance, a given partisan may assign 70 percent confidence to the proposition that their strategy for dealing with global warming will be effective. And though that is enough to hold a firm conviction and to act on it, still it is not so great that we can be certain that those who disagree are always wrong in this particular instance and should thus be curtailed permanently in their ability to influence public policy. Moreover, parties aggregate many issues, and even when partisans are convinced that they are entirely correct about some particular issue, they are less likely to believe they are perfectly right about every question in politics. Because the other side is the bearer of a view that possesses some probability of being right, and because assigning the probabilities is not always possible to do with complete certainty, it is reasonable to view the other side as a legitimate contender in politics and thus refrain from hampering electoral fairness through abusive legalism.

Still, it is always possible that partisans of a particular stripe both see themselves to be, and are in fact, correct across the package of views that define the party. The partisans who are correct may also understand why they are correct and may attach a high degree of certainty to 
their convictions. Epistemic humility in certain circumstances may impose a level of uncertainty and doubt unwarranted by the evidence. In these cases, the commitment to political pluralism may come from epistemic respect. This means viewing opponents as rational and moral agents, and therefore as persuadable - even and especially when they are wrong. Conversely, if partisans know that their opponent is fundamentally wrong and also considers them as "epistemically hopeless" (Fritz, 2019), or beyond the capacity of being persuaded by evidence and arguments, there are few reasons left to refrain from restricting their chances in the electoral contest. But this is a high price to pay, even if some are in fact unpersuadable. Regarding our opponents in an epistemically hopeful way-regarding them as persuadable even when we can find no evidence to support the view — may be an act of faith. But it is the kind of faith that democracy requires, at least at times. At a very minimum, then, being committed to political pluralism means considering opponents as persuadable in principle regardless of whether they are in fact, and this because we view them as moral equals and rational agents in the political community.

Even if it is unlikely, and perhaps undesirable, for partisans to uphold a stringent understanding of moral pluralism as their world view, epistemic humility and epistemic respect constitute two powerful normative reasons for affirming political pluralism. These include the ideas that the whole truth is rarely the exclusive property of one side, that practical questions of political significance are difficult and many-sided, and that even where opponents are wrong, they may be persuadable and worthy of respect. While few partisans might be inclined to detail these reasons with any precision, it is reasonable to expect partisans to learn epistemic humility or at least epistemic respect in the course of contesting and compromising with the other side. We assume that these normative reasons - a conviction about what is right - have motivational force and guide political behaviour. They lead mainstream partisans to accept the legitimacy of 
those they wish to defeat in an election, and thus to refrain from the strategic manipulation of democratic institutions in an effort to hamper electoral fairness.

\section{Pluralist partisans and the challenge of institutional reform}

In this concluding section, we discuss further what it means for pluralist partisans to resist abusive legalism and preserve electoral fairness, given the democratic necessity of institutional reform. We argue that partisans committed to political pluralism will not engage in institutional reforms that upset equal terms of competitions between political parties, with two main exceptions: when such reforms allow for the extension of political rights, and when they are necessary to the survival of the democratic regime.

The solution to abusive legalism cannot be to place all reform out of reach. The fact that institutions can be reformed through legal, including constitutional channels, is not only unavoidable but is obviously a necessary tool for democratic progress. Even those democracies that have the oldest institutional settlements, such as the United Kingdom or the United States, have undergone wide-ranging transformations in the past two centuries - whether through changes to political custom, the evolution of case law, or the intervention of ordinary legislative chambers - many of which have contributed to reinforce checks on political power, extend political and civil rights, and broadly consolidate rather than undermine democratic institutions (Alexander, 2002). Solidifying institutions such that they are immune to any change is not only unrealistic given the unavoidable persistence of loopholes, but harmful to the democratic project. This means we need to explore what type of institutional reform is expressive of a commitment to political pluralism.

As a general rule, pluralist partisans will engage in reforms that do not upset electoral fairness and fair terms of competition among rival political parties. This means in practice that pluralist partisans will be reluctant to adopt institutional reforms that have such widely disparate 
impacts on different political parties that they are viewed by some parties as unfair. We emphasize that the test for pluralist partisans is not entirely justificatory (i.e., can an argument be made for the fairness of a particular institutional change) but also perceptual (do various parties view it as fair). As with most examples of legal changes that favour one party over another, there are many good arguments that partisans may use to justify them, and when taken in isolation these reforms would most often not be damaging to democracy. However, reforms with widely disparate electoral impacts are likely to be perceived by opponents as eliminating or severely hampering their chances to obtain political power, thereby creating a sense that the constitutional settlement is unfair. In the worst cases, this may create a precedent that provides a reason for less pluralist political actors to engage in more blatant abusive legalism when they obtain political power in future contests - a "tit for tat" exchange that culminates in a condition where parties view prospect of their rivals holding power as an existential threat.

As a matter of principle, therefore, pluralist partisans will uphold the existing constitutional settlement, and only engage in changes that are not perceived as disadvantaging some mainstream parties more than others. Many electoral reforms in European democracies in the late $19^{\text {th }}$ and early $20^{\text {th }}$ century in Western Europe would not pass this test. As shown by Boix, these comforted the strategic interests of governing parties by maximizing their parliamentary representation: conservative parties especially adopted proportional systems when new socialist contenders were in a position to obtain majorities, and majoritarian systems when they were not (Boix, 1999). Conversely, the history of Western Europe also includes many examples of reforms that have enhanced electoral fairness - the end of the Second World War created a strong impetus for imposing additional checks on governmental power through 
the establishment in many countries of independent authorities of electoral regulation. ${ }^{7}$ Reforms that raise the procedural thresholds for constitutional changes may also enhance the perception that an electoral process is fair. For example, after the Hungarian Socialist Party obtained a twothird majority in the 1994 Parliamentary elections, they amended the constitution to raise the threshold for abolishing it - thereby reinforcing brakes not only on the political power of future majorities, but also on their own.

We nevertheless acknowledge two major exceptions to this general rule. First, a commitment to pluralism is consistent with reforms that extend access to power to a greater number of citizens and create new avenues for citizen influence, even when these benefit some parties disproportionately. Franchise expanding reforms, for instance, are often more favourable to some parties than others. This was the case with the nineteenth century extension of the franchise, which consolidated the legitimacy of American parties in the Jacksonian era, and which gave the British Parliament more weight in its bid to control government with the support of newly enfranchised voters (Sartori, 1976, ch. 1; Schattschneider, 2009 [1942]). Comparably, many Western majorities have amended constitutions in the second half of the twentieth century to introduce or enlarge the scope for measures of direct democracy, while parties have themselves become increasingly internally democratic in their decision-making process (Cross \& Katz, 2013). While disadvantaged parties might view such reforms as unfair, extending the political rights of citizens serves the cause of democracy in the largest sense. Pluralist partisans can defensibly pursue reforms that champion the very principle of political

\footnotetext{
${ }^{7}$ Some of the institutional changes that have limited the power of political majorities in the second half of the $20^{\text {th }}$ century - for example the multiplication of independent Central Banks or the integration of national legal systems into the European Union - have nevertheless had adverse effects, creating different kinds of democratic deficits through the depoliticization of issues of political significance. For some commentators these may constitute borderline cases, whereby partisans do not directly increase their own power through such reforms, and thus do not formally erode electoral fairness, but nevertheless entrench institutionally a pro-market and small government political agenda (see for instance Hay, 2007; Mair, 2003; Mouffe, 2005).
} 
pluralism by empowering a greater diversity of voices, even when these penalise their opponents.

The second exception is more delicate, more in tension with the principle of political pluralism - and more open to abuse. This concerns cases when restricting the rights of political opponents is necessary to protect liberal democracy from an imminent and serious threat. In the context of the World Wars for instance, most democracies in Europe declared a state of emergency or its equivalent, granting the government temporary exceptional powers. While these types of measures clearly favoured the party in power over its opposition, they can be justified by the exceptional and drastic circumstances faced by European nations at the time. Other examples include using measures of democratic defence to ban political parties that openly vow to overthrow the democratic system with the use of violence (Rosenblum 2008, 412-455). For instance, democracies that adopted such measures against fascist parties during the inter-war era have had greater chances of survival than those that accommodated such parties (Capoccia, 2004). Only if partisans have a deep commitment to political pluralism and recognize the legitimacy of their opponents can democracy hope to survive in such trying times. Indeed, threats to the democratic state also create ideal circumstances for anti-pluralist actors to justify more wide-ranging measure that more permanently undermine democratic institutions and consolidate their own power-as currently exemplified by the evolution of the Turkish State since the 2016 coup d'Etat attempt (Cinar, 2019; Sözen, 2019).

This exception does not justify partisan retaliation against anti-pluralist actors that employ abusive legalism. Pluralist partisans will only employ measures that are proportionate and necessary to defend democracy against imminent and serious threats. In the current context, as discussed above, abusive legalism does not fit this definition: it constitutes a long-term and incremental threat to democracy rather than an immediate one. In such cases, further retaliation is likely to be perceived as unfair by the opposing camp and accelerate rather than halt 
democratic demise. For instance, consider how the Democratic Party in the US is increasingly tempted to respond in kind to the Republican's abusive legalism. This case involves judicial appointments rather than electoral rules per se, but it highlights the difficulties involved in responding to abusive legalism. In 2016, the Republican dominated Senate refused to consider the nomination by President Obama of Merrick Garland to the US Supreme Court, only to accept the nomination of Neil Gorsuch after the election of Donald Trump in November. In response, a growing number of Democrats have started arguing in favour of expanding the size of the U.S Supreme Court ("court packing") in the event they come to control the Presidency and the Senate, in order to offset the conservative tilt of the Court (Matthews, 2018). While the second suggested change comes as a response to the first, neither is justifiable from a pluralist standpoint: both measures interrupt long-standing norms and customary procedures to favour the deciding party over its opponents, and neither is a proportionate and necessary response to an immediate and serious threat against democracy. Even if retaliation against abusive legalism may be more justifiable than abusive legalism itself, it cannot be perceived as fair by opponents and thus erodes support for all norms and settled procedures. The end of a tit-for-tat cycle cannot be a stable democratic order. Instead, it nourishes an escalation of anti-pluralist sentiment which, ultimately, can only encourage further abusive legalism and undermine the democratic order.

\section{Conclusion}

We have argued that the resilience of procedures contributing to electoral fairness, and thus of democracy defined in minimal terms, depends on partisans who are committed to political pluralism. Pluralist partisanship is not solely a theoretical ideal, but an empirical condition for the endurance of basic procedures ensuring fair competition among political parties. The aspiration to design institutions that are self-maintaining was born of the realist 
suspicion that normative reasons are unreliable. However, the phenomenon of abusive legalism shows that even the most robust institutional designs are insufficient on their own to arrest incremental forms of democratic backsliding in the absence of this deeper normative commitment. Democracy is more fragile than we like to think: it ultimately depends on the existence of norms that have emerged over time in certain con- texts (Sartori, 1976), but might recede. The increasing dominance of the sort of populism that combines anti-pluralist discourse with institutional practices of abusive legalism (Müller, 2016), is a poignant reminder of this. The problem is not merely that pluralist norms might be unreliable, but also that applying them in concrete cases of institutional reform is profoundly challenging. That is why it will be imperative for partisans who are committed to political pluralism to resist the tit-for-tat descent that abusive legalism invites.

\section{References}

Ackerman, B. (2018). We the People: The Civil Rights Revolution (Vol. 3): Harvard University Press.

Albertazzi, D., \& Mueller, S. (2013). Populism and Liberal Democracy: Populists in Government in Austria, Italy, Poland and Switzerland. Government and Opposition, 48(3), 343-371. doi:10.1017/gov.2013.12

Alexander, G. (2001). Institutions, Path Dependence, and Democratic Consolidation. Journal of Theoretical Politics, 13(3), 249-269.

Alexander, G. (2002). Institutionalized uncertainty, the rule of law, and the sources of democratic stability. Comparative Political Studies, 35(10), 1145-1170. 
Ball, T. (1989). Party. In T. Ball, J. Farr, \& R. L. Hanson (Eds.), Political Innovation and Conceptual Change (pp. 155-176). Cambridge: Cambridge University Press.

Batory, A. (2008). The politics of EU accession: Ideology, party strategy and the European question in Hungary. Manchester: Manchester University Press.

Beitz, C. R. (1989). Political Equality: An Essay in Democratic Theory. Princeton: Princeton University Press.

Bermeo, N. (2016). On democratic backsliding. Journal of Democracy, 27(1), 5-19.

Blokker, P. (2019). Populism as a constitutional project. International Journal of Constitutional Law, 17(2), 536-553. doi:10.1093/icon/moz028

Blokker, P., Bugaric, B., \& Halmai, G. (2019). Introduction: Populist constitutionalism: Varieties, complexities, and contradictions. German Law Journal, 20(3), 291-295. doi: $10.1017 / \mathrm{glj} .2019 .24$

Bogaards, M. (2018). De-democratization in Hungary: diffusely defective democracy. Democratization, 1-19. doi:10.1080/13510347.2018.1485015

Boix, C. (1999). Setting the Rules of the Game: The Choice of Electoral Systems in Advanced Democracies. The American Political Science Review, 93(3), 609-624.

Bonotti, M. (2011). Conceptualizing political parties: A normative framework. Politics, 31(2), 19-26.

Capoccia, G. ( 2004). Defence of democracy against the extreme-right in inter-war Europe, A past still present? . In R. Eatwell \& C. Mudde (Eds.), Western democracies and the new extreme right challenge. London: Routledge.

Casal Bértoa, F., \& Mair, P. (2010). Two decades on: how institutionalized are the postcommunist party systems? . EUI Working Paper, 3.

Christiano, T. (1996). The Rule of the Many: Fundamental Issues in Democratic Theory. Boulder, Colorado: Westview Press.

Cinar, K. (2019). Decline of Democracy in Turkey. London: Routledge.

Clark, T. D. (2002). Beyond post-communist studies: political science and the new democracies of Europe. Armonk N.Y.: M.E. Sharpe.

Coppedge, M. (2012). Democratization and Research Methods: Cambridge University Press.

Cross, W. P., \& Katz, R. S. (Eds.). (2013). The challenges of intra-party democracy. Oxford: Oxford University Press.

Cruickshank, J. (2014). Democracy versus the Domination of Instrumental Rationality: Defending Dewey's Argument for Democracy as an Ethical Way of Life. Humanities, $3(1), 19$.

Dahl, R. A. (1956). A preface to democratic theory. Chicago: University of Chicago Press.

Dahl, R. A. (1971). Polyarchy: participation and opposition. New Haven: Yale University Press.

Diamond, L., \& Plattner, M. F. (Eds.). (2006). Electoral Systems and Democracy: John Hopkins University.

Diamond, L. J. (1994). Toward Democratic Consolidation. Journal of Democracy, 5(3), 4-17. 
Disch, L. (2011). Toward a Mobilization Conception of Democratic Representation. American Political Science Review, 105(01), 100-114.

Dovi, S. L. (2007). The good representative. Malden MA: Blackwell Pub.

Downs, A. (1957). An economic theory of democracy. New York: Harper \& Row.

Easton, D. (2009). A Re-assessment of the Concept of Political Support. British Journal of Political Science, 5(04), 435-435. doi:10.1017/s0007123400008309

Elliott, J. E. (1994). Joseph A. Schumpeter and The Theory of Democracy. Review of Social Economy, 52(4), 280-300.

Ezrow, L., \& Xezonakis, G. (2011). Citizen satisfaction with democracy and parties' policy offerings. Comparative Political Studies, 44(9), 1152-1178.

Freedom House. (2006). Freedom in the World Report. Retrieved from https://freedomhouse.org/report/freedom-world/freedom-world-2006

Freedom House. (2019a). Country report for Hungary. Retrieved from https://freedomhouse.org/report/freedom-world/2019/hungary

Freedom House. (2019b). Democracy in Retreat. Freedom In The World Report. Retrieved from https://freedomhouse.org/report/freedom-world/freedom-world-2019

Fritz, J. (2019). Ethics and Epistemic Hopelessness. Dartmouth University. Paper Presented at the 2019 workshop on Truth, Power and Democracy.

Galston, W. A. (2002). Liberal pluralism: the implications of value pluralism for political theory and practice. Cambridge, New York: Cambridge University Press.

Galston, W. A. (2005). The practice of liberal pluralism. Cambridge, New York: Cambridge University Press.

Ganghof, S. (2016). Reconciling Representation and Accountability: Three Visions of Democracy Compared. Government and Opposition, 51(2), 209-233.

Grzymala-Busse, A. (2007). Rebuilding Leviathan : party competition and state exploitation in post-communist democracies. Cambridge; New York: Cambridge University Press.

Hall, P. A., \& Taylor, R. C. R. (1996). Political Science and the Three New Institutionalisms. Political Studies, 44(5), 936-957.

Hallowell, J. H. (1954). The moral foundation of democracy. Chicago: Chicago University Press.

Hay, C. (2007). Why we hate politics. Cambridge: Polity Press.

Herman, L. E. (2016). Re-evaluating the post-communist success story: party elite loyalty, citizen mobilization and the erosion of Hungarian democracy. European Political Science Review, 8(2).

Herman, L. E. (2017). Democratic Partisanship: From Theoretical Ideal to Empirical Standard. American Political Science Review, 111(4).

Huntington, S. P. (1991). The third wave: democratization in the late twentieth century. Norman: University of Oklahoma Press.

Iyengar, S., Lelkes, Y., Levendusky, M., Malhotra, N., \& Westwood, S. J. (2019). The Origins and Consequences of Affective Polarization in the United States. Annual review of Political Science, 22(1), 129-146. doi:10.1146/annurev-polisci-051117-073034 
Kant, I. (1795). First supplement of the guarantee for perpetual peace.

Kateb, G. (1981). The Moral Distinctiveness of Representative Democracy. Ethics, 91(3), 357374.

Kato, J. (1996). Institutions and Rationality in Politics - Three Varieties of Neo-Institutionalists. British Journal of Political Science, 26(4), 553-582.

King, C. (2000). Post-postcommunism - Transition, Comparison and the End of "Eastern Europe". World Politics, 53, 143-172.

Landau, D. (2013). Abusive Constitutionalism. UC Davis Law Review, FSU College of Law, Public Law Research, 189(Paper No. 646).

Lardeyret, G. (2006). The problem with proportional representation. In L. Diamond \& M. F. Plattner (Eds.), Electoral Systems and Democracy: John Hopkins University.

Lefort, C. (1988). Democracy and political theory. Cambridge: Polity in association with Basil Blackwell.

Levitsky, S., \& Way, L. A. (2020). The New Competitive Authoritarianism. Journal of Democracy, 31(1), 51-65.

Levitz, P., \& Pop-Eleches, G. (2010). Why No Backsliding? The European Union's Impact on Democracy and Governance Before and After Accession. Comparative Political Studies, 43(4), 457-485. doi:10.1177/0010414009355266

Lewis, P. G. (2006). Party Systems in Post-communist Central Europe: Patterns of Stability and Consolidation. Democratization, 13(4), 562-583.

Lijphart, A. (1991). Constitutional Choices for New Democracies. Journal of Democracy, 2(1), $72-84$.

Lijphart, A. (2012). Patterns of Democracy, Government Forms and Performance in ThirtySix Countries (2nd ed.): Yale University Press.

Linz, J. (1978). The breakdown of democratic regimes: crisis, breakdown, and reequilibration. Baltimore: Johns Hopkins University Press.

Lührmann, A., Grahn, S., Morgan, R., Pillai, S., \& Lindberg, S. I. (2019). State of the world 2018: democracy facing global challenges. Democratization, 26(6), 895-915. doi:10.1080/13510347.2019.1613980

Lührmann, A., \& Lindberg, S. I. (2019). A third wave of autocratization is here: what is new about it? Democratization, 26(7), 1095-1113. doi:10.1080/13510347.2019.1582029

Macedo, S. (1990). Liberal virtues: citizenship, virtue and community in liberal constitutionalism. Oxford: Clarendon.

Madison, J. (1787, November 23). Federalist \#10. Retrieved from https://www.congress.gov/resources/display/content/The+Federalist+Papers

Madison, J. (1788, February 8). Federalist \#51. Retrieved from https://www.congress.gov/resources/display/content/The+Federalist+Papers

Mair, P. (2003). Popular democracy and EU enlargement. East European Politics \& Societies, 17(1), 58-65. doi:10.1177/0888325402239683

Mandeville, B. (1732). The Fable of the Bees, or Private Vices, Public Benefits. Retrieved from https://oll.libertyfund.org/titles/mandeville-the-fable-of-the-bees-or-private-vicespublick-benefits-vol-1 
Mansbridge, J. (2003). Rethinking Representation. The American Political Science Review, 97(4), 515-528.

Matthews, D. (2018, October 5). Court-packing, Democrats' nuclear option for the Supreme Court, explained. Vox. Retrieved from https://www.vox.com/2018/7/2/17513520/courtpacking-explained-fdr-roosevelt-new-deal-democrats-supreme-court

McGann, A. J. (2006). The Logic of Democracy: Reconciling Equality, Deliberation, and Minority Protection Ann Arbor: University of Michigan Press.

McGann, A. J. (2013). Fairness and Bias in Electoral Systems. In J. H. Nagel \& R. M. Smith (Eds.), Representation - Elections and Beyond (pp. 90-113). Philadelphia: University of Pennsylvania Press.

Meisburger, T. M. (2012). Getting majoritarianism right. Journal of Democracy, 23(1), 155 163

Meyerrose, A. M. (2020). The Unintended Consequences of Democracy Promotion: International Organizations and Democratic Backsliding. Comparative Political Studies, Online First. doi:10.1177/0010414019897689

Mouffe, C. (2000). The democratic paradox. New York: Verso.

Mouffe, C. (2005). On the political. New York: Routledge.

Mudde, C. (2007). Populist radical right parties in Europe. Cambridge: Cambridge University Press.

Muirhead, R. (2014). The Promise of Party in a Polarized Age: Harvard University Press.

Muirhead, R., \& Rosenblum, N. L. (2006). Political Liberalism vs. "The Great Game of Politics": The Politics of Political Liberalism. Perspectives on Politics, 4(01), 99-108.

Müller, J.-W. (2017). Populism and Constitutionalism. In C. R. Kaltwasser, P. A. Taggart, P. O. Espejo, \& P. Ostiguy (Eds.), The Oxford Handbook of Populism. Oxford: Oxford University Press.

Norris, P. (2017a). Is Western Democracy Backsliding? Diagnosing the Risks. The Journal of Democracy, April.

Norris, P. (2017b, January 7). U.S Elections rank last among all Western Democracies. Electoral Integrity Project website. Retrieved from https://www.electoralintegrityproject.com/eip-blogs/2017/1/7/its-even-worse-than-thenews-about-north-carolina-american-elections-rank-last-among-all-westerndemocracies

O'Donnell, G., Schmitter, P., \& Whitehead, L. (1986). Transitions from authoritarian rule. Baltimore: Johns Hopkins University Press.

Öniş, Z., \& Kutlay, M. (2019). Reverse transformation? Global shifts, the core-periphery divide and the future of the EU. Journal of Contemporary European Studies, 1-19. doi:10.1080/14782804.2019.1708280

Pateman, C. (1971). Political Culture, Political Structure and Political Change. British Journal of Political Science, 1(Jul), 291-305.

Pateman, C. (2007 [1970]). Recent theories of democracy and the 'classical myth'. In M. Saward (Ed.), Democracy: critical concepts in political science (Vol. 3). London: Routledge. 
Pech, L., \& Scheppele, K. L. (2017). Illiberalism Within: Rule of Law Backsliding in the EU. Cambridge Yearbook of European Legal Studies, 19, 3-47. doi:10.1017/cel.2017.9

Przeworski, A. (1991). Democracy and the market: political and economic reforms in Eastern Europe and Latin America. Cambridge: Cambridge University Press.

Przeworski, A. (1999). Minimalist conception of democracy: a defense. In I. Shapiro \& C. Hacker-Cordón (Eds.), Democracy's value. Cambridge, New York: Cambridge University Press.

Przeworski, A. (2015). Acquiring the habit of changing government through elections. Comparative Political Studies, 48(1), 101-129.

Renwick, A. (2010). The politics of electoral reform : changing the rules of democracy. Cambridge/New York: Cambridge University Press.

Reynolds, A. (2016, December 22). North Carolina is no longer classified as a democracy. News Observer. Retrieved from https://www.newsobserver.com/opinion/oped/article122593759.html

Reynolds, A., \& Carey, J. M. (2012). Debating electoral systems, Getting Elections Wrong. Journal of Democracy, 23(1), 164-168.

Rosenblum, N. L. (1998). Membership and morals: the personal uses of pluralism in America. Princeton, N.J.: Princeton University Press.

Rosenblum, N. L. (2008). On the side of the angels: an appreciation of parties and partisanship. Princeton N.J.: Princeton University Press.

Rosenblum, N. L. (Ed.) (1989). Liberalism and the moral life. London: Harvard University Press.

Ryn, C. G. (1978). Democracy and the ethical life: a philosophy of politics and community. Baton Rouge: Baton Rouge : Louisiana State University Press.

Sartori, G. (1976). Parties and party systems: a framework for analysis. Cambridge: Cambridge University Press.

Saward, M. (2010). The representative claim. Oxford: Oxford University Press.

Schattschneider, E. E. (2009 [1942]). Party government. New Brunswick: Transaction publishers.

Scheppele, K. L. (2013a). The Rule of Law and the Frankenstate: Why Governance Checklists Do Not Work. Governance, 26(4), 559-562. doi:doi:10.1111/gove.12049

Scheppele, K. L. (2013b). The trajectory of democracy - why Hungary matters. Paper presented at the Hearing of the commission on security and cooperation in Europe, Washington. http:/www.csce.gov/index.cfm?FuseAction=ContentRecords.ViewWitness\&Content Record $\mathrm{id}=1496 \&$ ContentType $=$ D\&ContentRecordType $=$ D\&ParentType $=\mathrm{H} \& C F I D=$ 26287708\&CFTOKEN $=90075857$

Scheppele, K. L. (2018). Autocratic Legalism. The University of Chicago Law Review, 85, 545562.

Schmidt, V. A. (2008). Discursive Institutionalism: The Explanatory Power of Ideas and Discourse. Annual review of Political Science, 11(1), 303-326.

Schmitter, P. C., \& Karl, T. L. (1991). What Democracy Is . . . and Is Not. Journal of Democracy, 2(3), 75-88. 
Schneider, C. Q., \& Schmitter, P. C. (2004). Liberalization, transition and consolidation: measuring the components of democratization. Democratization, 11(5), 59-90.

Schumpeter, J. A. (1950). Capitalism, socialism, and democracy. New York: Harper.

Sedelmeier, U. (2014). Anchoring Democracy from Above? The European Union and Democratic Backsliding in Hungary and Romania after Accession. JCMS: Journal of Common Market Studies, 52(1), 105-121. doi:10.1111/jcms.12082

Sedelmeier, U. (2017). Political safeguards against democratic backsliding in the EU: the limits of material sanctions and the scope of social pressure. Journal of European Public Policy, 24(3), 337-351. doi:10.1080/13501763.2016.1229358

Shapiro, I. (2018, March 12). Democratic competition: The good, the bad and the ugly. American Academy in Berlin. Retrieved from https://www.americanacademy.de/event/democratic-competition-good-bad-ugly/

Sikk, A. (2005). How unstable? Volatility and the genuinely new parties in Eastern Europe. European Journal of Political Research, 44, 391-412.

Skinner, Q. (1973). The Empirical Theorists of Democracy and Their Critics: A Plague on Both Their Houses. Political Theory, 1(3), 287-306. doi:10.2307/190588

Smith, A. (1776). An Inquiry into the Nature and Causes of the Wealth of Nations. Cannan edition. Retrieved from https://oll.libertyfund.org/titles/smith-an-inquiry-into-thenature-and-causes-of-the-wealth-of-nations-cannan-ed-vol-1

Sözen, Y. (2019). Competition in a Populist Authoritarian Regime: The June 2018 Dual Elections in Turkey. South European Society and Politics, 24(3), 287-315. doi:10.1080/13608746.2019.1688515

Stewart, C. I. (2017). The 2016 U.S. Election: Fears and Facts About Electoral Integrity. Journal of Democracy, 28 (2), 50-62.

Thurber, J. A., \& Yoshinaka, A. (Eds.). (2015). American gridlock : the sources, character, and impact of political polarization. New York: Cambridge University Press.

van Biezen, I., \& Saward, M. (2008). Democratic Theorists and Party Scholars: Why They Don't Talk to Each Other, and Why They Should. Perspectives of Politics, 6(1), 21-35.

van der Hout, E., \& McGann, A. J. (2009). Liberal political equality implies proportional representation. Social Choice and Welfare, 33, 617-627.

Varol, O. O. (2015). Stealth Authoritarianism. Iowa Law Review, 100, 1673-1742.

Werner-Müller, J. (2016). What is Populism? Philadelphia: University of Pennsylvania Press.

Weyland, K. (2002). Limitations of rational-choice institutionalism for the study of Latin American politics. Studies in Comparative International Development, 37(1), 57-85. doi:10.1007/BF02686338

White, J. (2009). The Social Theory of Mass Politics. The Journal of Politics, 71(01), 96-112.

White, J., \& Ypi, L. (2010). Rethinking the Modern Prince: Partisanship and the Democratic Ethos. Political Studies, 58(4), 809-828.

White, J., \& Ypi, L. (2011). On Partisan Political Justification. American Political Science Review, 105(02), 381-396.

White, J., \& Ypi, L. (2016). The meaning of partisanship. Oxford: Oxford University Press. 
Williams, D. L. (2014). Rousseau's social contract: an introduction. Cambridge: Cambridge Universiy Press.

Williams, M. S. (2000). Voice, Trust, and Memory: Marginalized Groups and the Failings of Liberal Representation. Princeton: Princeton University Press. 